$[\mathrm{XleP}]$

\title{
Integrated magnetostratigraphy and biostratigraphy of the upper Pliocene-lower Pleistocene from the Monte Singa and Crotone areas in Calabria, Italy
}

\author{
J.D.A. Zijderveld ${ }^{a}$, F.J. Hilgen ${ }^{\text {a }}$, C.G. Langereis ${ }^{\text {a }}$, P.J.J.M. Verhallen ${ }^{\text {b }}$ \\ and W.J. Zachariasse ${ }^{b}$ \\ ${ }^{a}$ Paleomagnetic Laboratory, Fort Hoofddijk, Budapestlaan 17, 3584 CD Utrecht, The Netherlands \\ ${ }^{b}$ Institute of Earth Sciences, Budapestlaan 4, 3584 CD Utrecht, The Netherlands
}

Received May 17, 1991; revision accepted October 21, 1991

\begin{abstract}
The results of a detailed magnetostratigraphic and biostratigraphic study of late Pliocene to early Pleistocene marine marl sequences from the Monte Singa and Crotone areas in Calabria, Italy are presented.

The magnetostratigraphy from the Monte Singa sequence ranges from below the Gauss/Matuyama boundary up to and including the lower Olduvai boundary. Normal polarities at a level corresponding to isotope stage 81 most probably represent the Réunion subchron. From the lower Olduvai boundary upward, a reliable magnetostratigraphy could not be established due to increased weathering of the marls, resulting in mainly secondary magnetizations.

The magnetostratigraphy from the composite sequence of the Crotone area belongs to a large part of the Matuyama Chron and includes the Olduvai subchron. The position of the lower and upper boundaries of the Olduvai subzone could be established more precisely than from earlier results. Moreover, the upper boundary of the Olduvai subzone poses an ambiguity: a relatively long normal polarity interval representing the main Olduvai subchron and corresponding to a duration of $115 \mathrm{ka}$ is followed by a short $(30 \mathrm{ka})$ reversed subchron and the short (15 ka) normal Vrica subchron. Another option, and more in accordance with the duration of the Olduvai subchron in literature, would be to consider the complete $\mathrm{N}-\mathrm{R}-\mathrm{N}$ polarity succession with a total duration of $160 \mathrm{ka}$ as representing the Olduvai subchron, implying that this Olduvai subchron has a short reversed interval in its upper part.

Linear interpolation and extrapolation yield ages for the most important late Pliocene--early Pleistocene biostratigraphic datum levels. An age of $1.69 \mathrm{Ma}$ is found for the Pliocene-Pleistocene boundary, using the conventional polarity time scale dated with radiometric results. However Hilgen [1], in correlating the sapropel groups and patterns to the precession curve of the Earth's orbit, obtained significantly different ages for the polarity transitions of the present study. According to this astronomically calibrated polarity time scale, the age of the Pliocene-Pleistocene boundary is $1.81 \mathrm{Ma}$.
\end{abstract}

\section{Introduction}

A long tradition in Pliocene stratigraphy has led to the definition of many stages and boundaries for this epoch in the Mediterranean. Most of the marine sedimentary sequences involved are located on the Italian peninsula. Good paleomagnetic control has long been lacking, however, and only recently have an increasing number of magnetostratigraphic studies been published on Pliocene land sections in the Mediterranean. The Miocene-Pliocene $(\mathrm{M} / \mathrm{P})$ boundary has been studied by various authors [2-4] and now has an age, according to the conventional radiometric time scale, of $4.86 \mathrm{Ma}$, slightly below the Thvera subchron. The early Pliocene and early late Pliocene have been the subject of detailed magnetostratigraphic and biostratigraphic research by Langereis and Hilgen [5] and Zachariasse et al. $[6,7]$.

The present study gives a new and detailed magnetostratigraphy and biostratigraphy for the Mediterranean upper Pliocene and lower Pleistocene from southern Italy. Paleomagnetic results for this time interval in Mediterranean land-based sections have been provided earlier by Tauxe et al. [8], who studied the Pliocene-Pleistocene boundary section of Vrica and the lower Se- 
maforo section in the Crotone area of northern Calabria. They concluded that the normal polarity interval in the middle of the Vrica section represents the Olduvai subchron. In addition, normal polarities were found in the top part of the section. However, the resolution obtained by Tauxe et al. [8] was not sufficient to define the lower and upper boundaries of the Olduvai subchron with adequate accuracy [1]. Moreover, originally the Semaforo-Vrica sequence was thought to be discontinuous. Therefore, we resorted to Monte Singa in adjacent southern Calabria (Fig. 1), where a continuous sequence of open-marine marls and clays - containing sapropelitic layers - is exposed in the upper Singa section. Due to poor paleomagnetic properties in the upper part of this Singa section, however, we had to revert to the Vrica section (Fig. 1), although in the present study sampling was carried out in appreciably more detail than previously [8]. Moreover, it could be shown that the alleged gap between the Semaforo and Vrica sections in fact does not exist [9].
With the present study, a major part of our research of the integrated magnetostratigraphy and biostratigraphy of the Mediterranean Pliocene recorded in land-based sections has been completed. The magnetostratigraphy, in combination with the orbitally forced sedimentary cycles, has resulted in a new and astronomically dated polarity time scale $[1,5,10-12]$.

\section{Sections and sampling}

\subsection{Monte Singa area}

Monte Singa comprises $225 \mathrm{~m}$ of well-exposed marine marls and clays which cover a considerable part of the Pliocene, including the Miocene-Pliocene $(\mathrm{M} / \mathrm{P})$ boundary and the Pliocene-Pleistocene $(\mathrm{P} / \mathrm{P})$ boundary. In the middle of the Pliocene, however, a substantial part is missing: a hiatus of approximately $1 \mathrm{Ma}$ corresponds to the interval of the uppermost part of the Gilbert Chron and a major part of the Gauss Chron [2,7]. The sequence below the hiatus (lower Singa) includes the $\mathrm{M} / \mathrm{P}$ boundary and
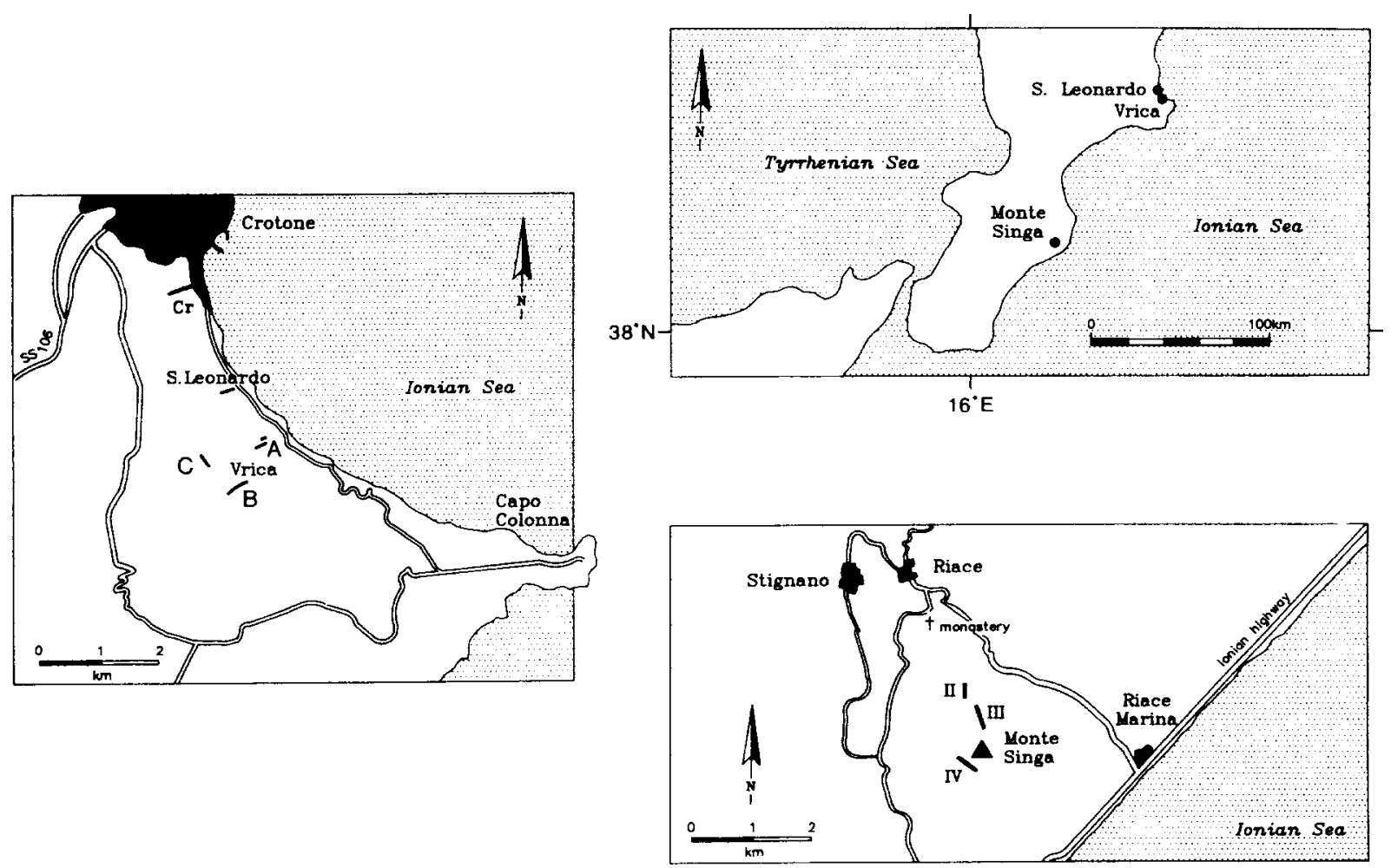

Fig. 1. Location of the studied sections. 
has been the subject of a study by Zijderveld et al. [2]. The sequence above the hiatus (upper Singa) is the subject of the present study. This upper Singa section is composed of three subsections (Singa II, III and IV) which are spread over the northeastern flanks of Monte Singa. The tilt of the strata is $5^{\circ}$ and $15^{\circ} \mathrm{SSE}$ for subsections Singa II and III respectively, and $5^{\circ} \mathrm{E}$ for subsection Singa IV. Subsections Singa II and IV end upwards at topographical highs and consequently their upper parts are strongly weathered.

The correlation between the subsections is based on frequently occurring sapropelitic layers. Although the composition of all these sapropelitic layers may not be in complete agreement with the more restricted redefinition for sapropels by Kidd et al. [13], we prefer to use the name "sapropel" in the original meaning of Olausson [14]. The sapropels are not distributed evenly throughout the stratigraphic record, but occur in distinct clusters (Fig. 2). Three large-scale clusters have been informally coded as the A, B and $C$ groups [15]. These large-scale clusters contain several small-scale clusters, each of which comprise two to four individual sapropels. The individual sapropels have been labeled according to their position in a cluster (A1-5, B1-7, C1-14; see fig. 2). The resulting complex pattern has been interpreted as interference patterns related to the Earth's orbital cycles $[1,10]$.

\subsection{Crotone area}

The Vrica section was formally designated as the Pliocene-Pleistocene $(\mathrm{P} / \mathrm{P})$ boundary stratotype [16] and has been intensely studied $[8,9,17-$ 20]. The section consists of three subsections, Vrica A, Vrica B and Vrica C, as originally designated by Selli et al. [18], and not to be confused with our sapropel labeling. This composite sequence shows a sapropel pattern similar to that found in the Singa section (Fig. 2). Most of these sapropels, as well as several other lithological marker levels, have informally been labeled as $a$ to $t$ by Selli et al. [18]. The $\mathrm{P} / \mathrm{P}$ boundary has been defined at the top of sapropel $e$ [16]. The sapropels in the Vrica section can be unambiguously correlated to the $\mathrm{B}$ and $\mathrm{C}$ cluster from the Singa section (Fig. 2; $[9,15]$ ). This correlation implies that the $\mathrm{P} / \mathrm{P}$ boundary in the upper Singa section must be placed at the top of sapropel C6.

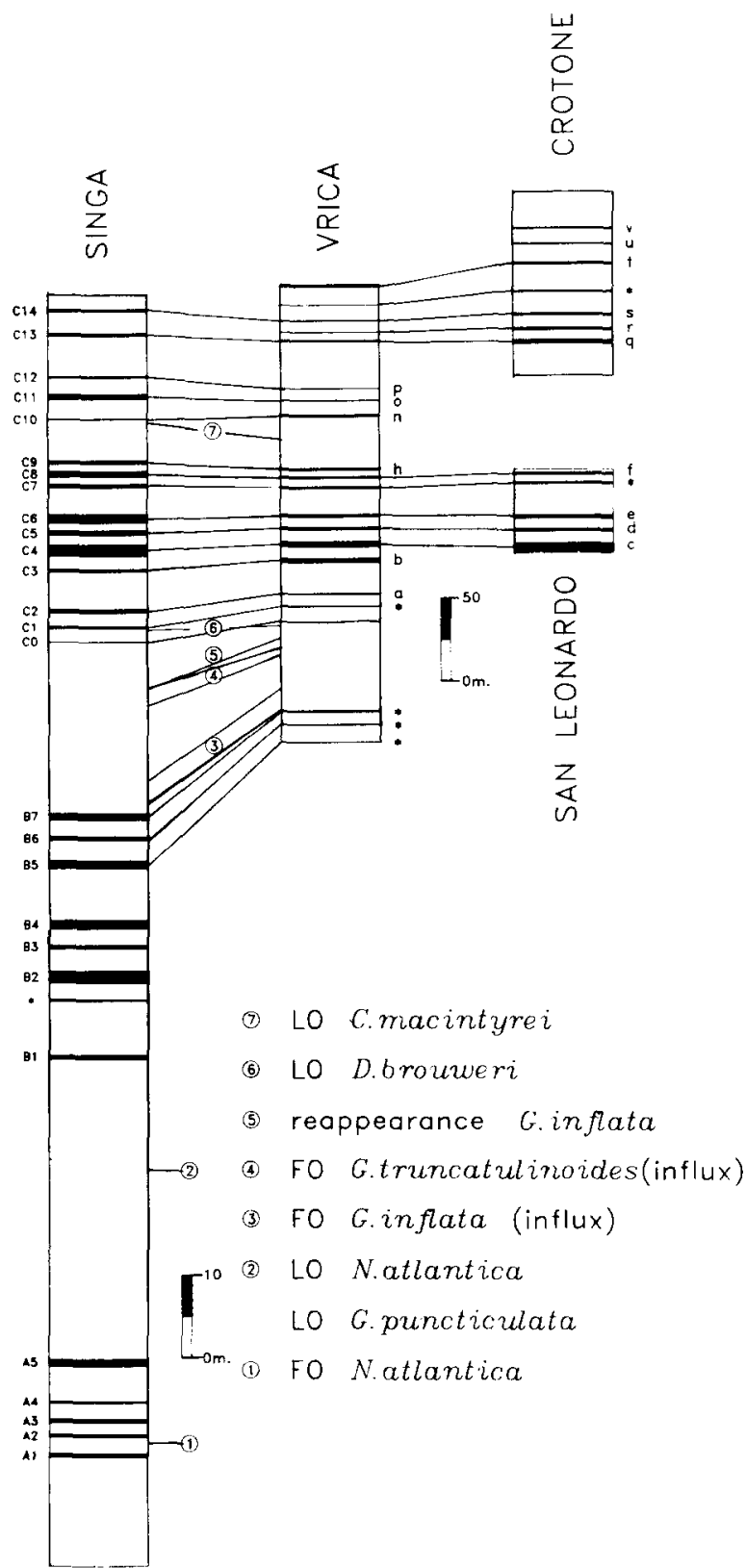

Fig. 2. Litho- and biostratigraphical correlations between the studied sections. The sapropels of the Singa and the Crotone area sections can be correlated one to one.

In the Vrica section the sequence from sapropel $c$ up to $f$, containing the upper boundary of the Olduvia subzone, occupies a visibly weathered interval. Therefore, in order to obtain better results and a higher resolution, this important interval was resampled in the San Leonardo section 


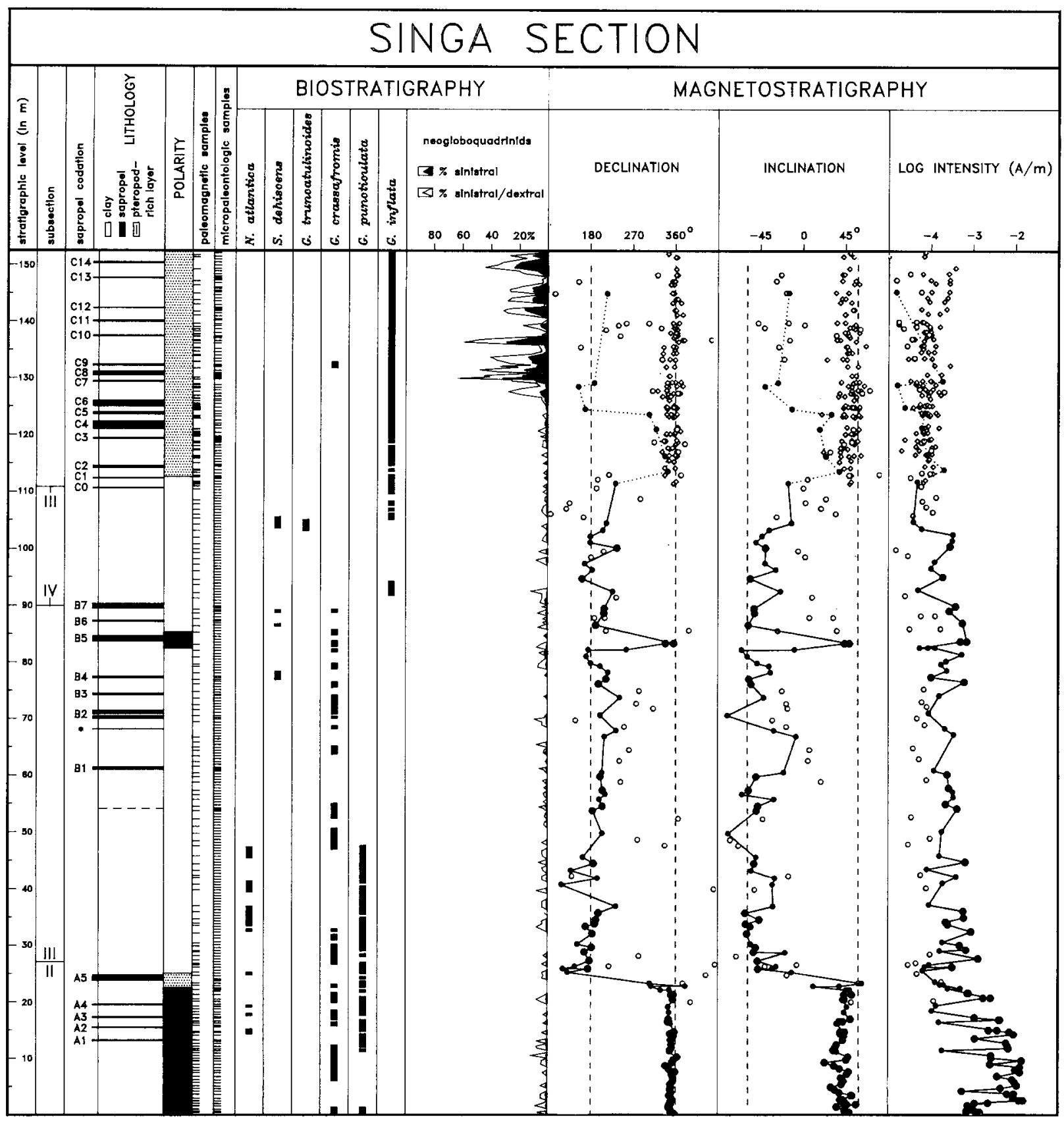

Fig. 3. Lithostratigraphy, biostratigraphy and magnetostratigraphy of the upper part of the Singa composite section. Regarding the characteristic remanent magnetization (ChRM) and remanence intensity of the upper Singa section, the analysis of the demagnetization diagrams involved the use of three reliability classes. The first class (larger dots) represents reliable characteristic remanent magnetizations (ChRM) of fresh marl samples, with almost no secondary component and a linear decrease towards the origin at temperatures higher than $200-250^{\circ} \mathrm{C}$. The second class (smaller dots) are less reliable ChRMs, with a relatively large secondary overprint resulting in the directions being less well determined, but the polarities are still reliable. The third class (circles) shows a large dominating secondary overprint and it is not always certain whether a direction is truly normal or whether only, or mostly, the overprint is seen; unreliable specimens are often from parts where no fresh unweathered sediment could be obtained. The plotted intensities are those taken (where possible) at 200 or $250^{\circ} \mathrm{C}$, i.e. after removal of the secondary present-day field magnetization. Diamonds denote magnetizations which have been interpreted as secondary only, corresponding intensities are those taken at $100^{\circ} \mathrm{C}$. Generally, lower intensities agree well with lower class magnetizations. 
(Figs. 1 and 2). For the present study the Vrica section is extended upwards by the Crotone section. This section could be tied to the Vrica section using sapropels $q, r$ and $s$ (Fig. 2). In the Crotone section the coding of Selli et al. [18] is supplemented with two extra sapropels, $u$ and $v$. Fresh samples could be obtained from below $q$ up to $u$, whereas between sapropels $u$ and $v$ this was impossible because of the extent of the weathering. With the exception of the Vrica $\mathrm{C}$ subsection and the upper part of the Crotone section where tilt $=5 \frac{1}{2}^{\circ} \mathrm{W}$, the tilt of the strata in the Vrica and Crotone area is uniformly $8 \frac{1}{2}^{\circ} \mathrm{W}$.

\subsection{Sampling}

Sampling was carried out by drilling at least two cores per stratigraphic level (site), using an electric drill and a portable generator. Strati-

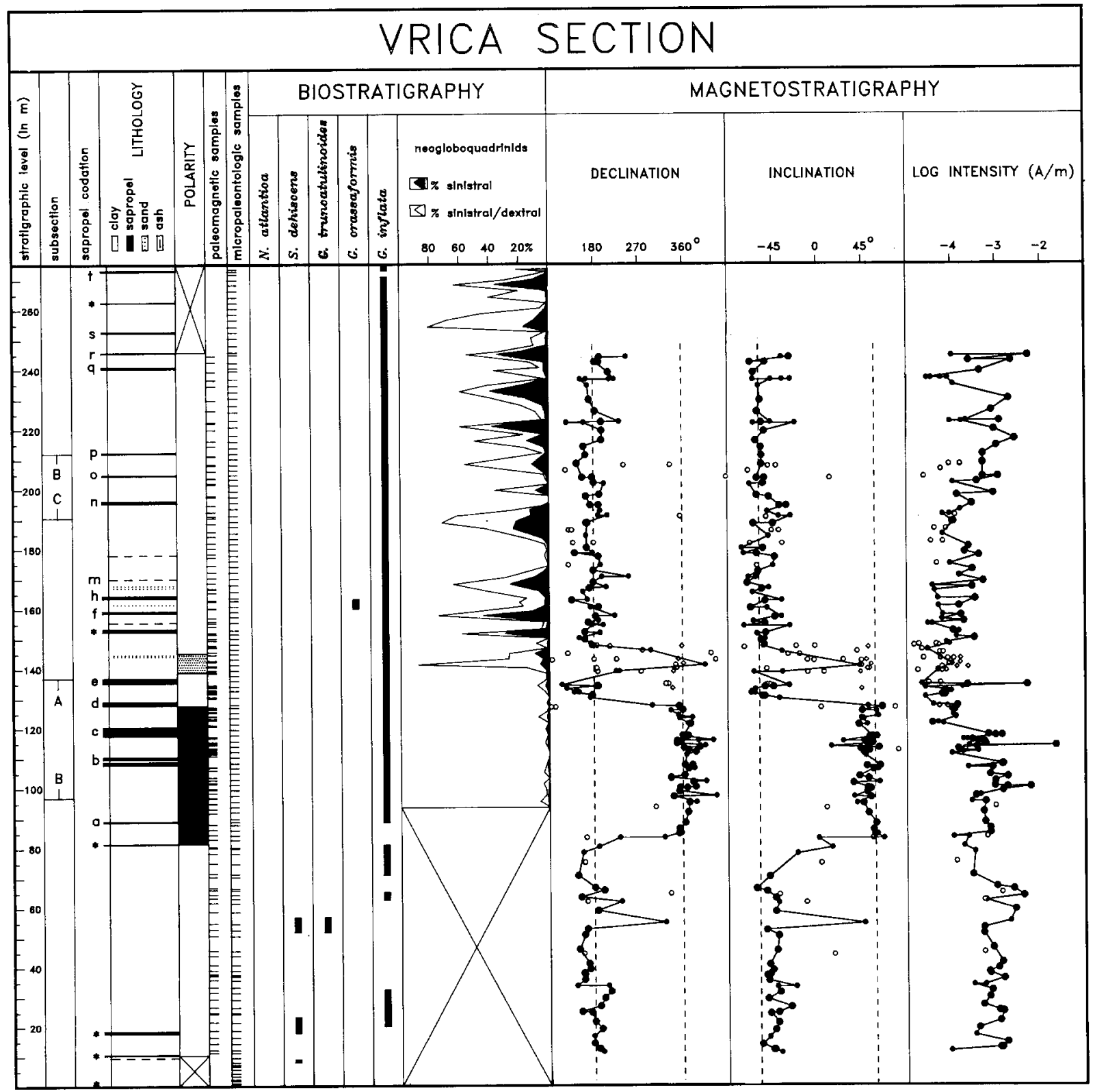

Fig. 4. Lithostratigraphy, biostratigraphy and magnetostratigraphy of the Vrica composite section. See caption to Fig. 3 for further explanation. 


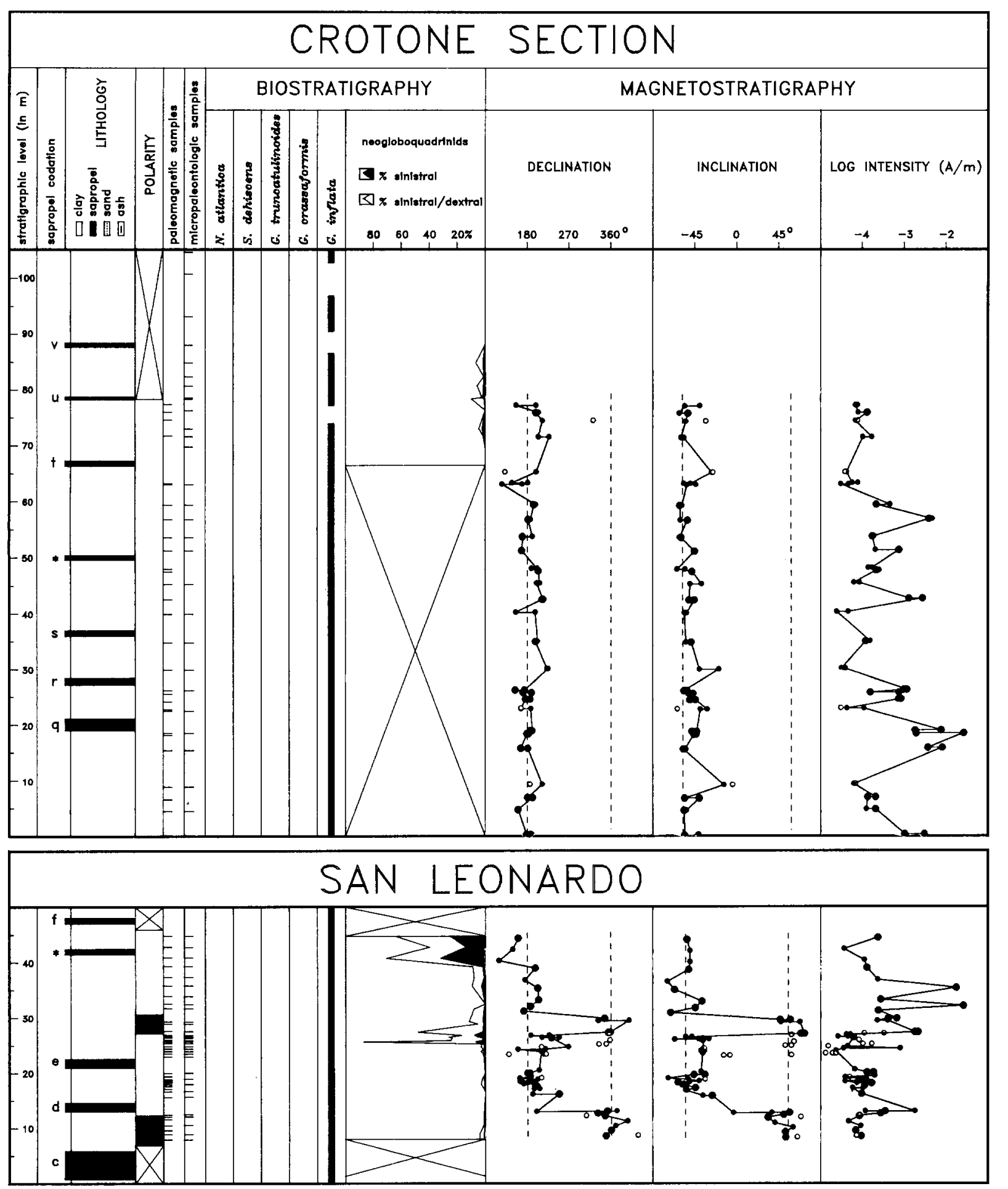

Fig. 5. Lithostratigraphy, biostratigraphy and magnetostratigraphy of the Crotone and San Leonardo sections. See caption to Fig. 3 for further explanation. 
graphic positions were accurately determined using distance, azimuth and angle between levels, and orientation of the bedding plane. Considerable efforts were made to remove the weathered surface and to drill in fresh, blue-coloured sediment. If the sediment proved to be too weathered, we refrained from taking samples (e.g., between sapropels $r$ and $s$ in subsection Vrica C). In several cases we have resampled parts of the sampling track if another gully appeared more suitable (i.e., fresher sediment). The freshness, colour and general appearance of each level and the core details were carefully registered. This sampling procedure has enabled us to assess the validity of the paleomagnetic results in a most reliable manner.

The upper Singa section was sampled during several field trips. More than 190 paleomagnetic sites have been recorded over the total stratigraphic interval of $155 \mathrm{~m}$ of marine marls (Fig. 3). In the Vrica section, 155 sites were sampled over a stratigraphic interval of $235 \mathrm{~m}$ up to sapropel $r$ (Fig. 4). In the Crotone section, 30 paleomagnetic sampling sites were sampled over the $80 \mathrm{~m}$ fresh interval up to sapropel $u$ (Fig. 5), whereas in the San Leonardo section 41 sites were taken over the paleomagnetically sampled $36 \mathrm{~m}$ interval (Fig. 5).

\section{Biostratigraphy}

The Singa/Vrica composite sequence ranges from the $G$. crassaformis Zone (Interval 6 of Spaak [21] and MPL 5 of Cita [22]) into the Pleistocene. The stratigraphic positions of selected calcareous nannofossil events in the Singa section have been taken from Driever ([23] and unpublished data).

The planktonic foraminiferal zonation is based primarily on the absence or presence of the marker species Globorotalia crassaformis, Globorotalia truncatulinoides, Sphaeroidinella dehiscens, Neogoboquadrina atlantica and the Globorotalia inflata group in fractions coarser than $125 \mu \mathrm{m}$ (Figs. 3, 4 and 5). The G. inflata group includes G. puncticulata in the lower part of the upper Singa section, and $G$. inflata in the upper part of the upper Singa section and in the Vrica, San Leonardo and Crotone sections.

In the upper Singa section, the first occurrence (FO) of $N$. atlantica is observed between sapro- pel A1 and A2 (Fig. 3). Subsequent occurrences of this species among the $\mathrm{A}$ cluster are found between $\mathrm{A} 3$ and $\mathrm{A} 4$ and between $\mathrm{A} 4$ and $\mathrm{A} 5$. Three more influxes occur in the thick homogeneous interval between the $A$ and $B$ sapropel clusters. These successive occurrences of $N$. atlantica have been correlated to glacial isotope stages 108, 106, 104, 100, 98 and 96 in DSDP Site 607 [7]. An even older influx of this species has recently been found slightly below the $\mathrm{A} 1$ in the Punta Piccola section on Sicily and correlates with stage 110 [24]. The last occurrence (LO) of $N$. atlantica in the Mediterranean is marked by the influx of this species at isotopic stage 96 and is synchronous with the final extinction of the species in the North Atlantic [7,25].

G. crassaformis is regularly but discontinuously present from the base of the upper Singa section up to sapropel B7 (Fig. 3). A last short-term influx is recorded around sapropel C9 (or $h$ ) in both the Singa and Vrica section. This influx, however, does not represent the actual last occurrence of this species in the Mediterranean, because younger occurrences have been also observed, for instance at ODP Site 653 in the Tyrrhenian Sea (Leg 107 [26]).

Rare and discontinuous occurrences of $S$. dehiscens are restricted to a short stratigraphic interval which extends from sapropel B4 to well below $\mathrm{C} 0$ (Fig. 3). The last occurrence (LO) of this species closely coincides with the FO of $G$. truncatulinoides. This FO corresponds to a first and brief influx followed by a long period of absence. This brief influx of $G$. truncatulinoides was previously reported from time-equivalent sections elsewhere in the Mediterranean [27] and marks a very distinct bio-event. The reappearance level is not reached in our sections.

$G$. puncticulata is almost continuously present from the base of the upper Singa section to its disappearance level between the A and B sapropel clusters. This level coincides exactly with the LO of $N$. atlantica. The LO of G. puncticulata is followed by a prolonged absence interval of the $G$. inflata group (i.e., second absence interval of Spaak [21]), while $G$. inflata enters the record above sapropel B7. This first occurrence of $G$. inflata represents a brief influx, whereafter this species vanishes from the record until a level situated below $\mathrm{C} 0$. From this level upwards, $G$. 
inflata is almost continuously present up to the top of our sections.

The percentage of sinistrally coiled neogloboquadrinids of the total of the neogloboquadrinids (excluding $N$. atlantica) as well as of the total of planktonic foraminifers has been determined. A first significant increase in left-coiling neogloboquadrinids is consistently observed slightly above the top of sapropel C6/e (Figs. 3, 4 and 5), i.e. the level which marks the $\mathrm{P} / \mathrm{P}$ boundary. Percentages of sinistrally coiled neogloboquadrinids display a highly fluctuating pattern from the $\mathrm{P} / \mathrm{P}$ boundary up to the top of the Vrica section.

\section{Magnetostratigraphic results of the sections}

Two specimens per sampling level have been progressively demagnetized, in general thermally and using small temperature increments (of 50 and $30^{\circ} \mathrm{C}$ ). Only a small number of samples has been treated with alternating magnetic fields. We divided the demagnetization results into three reliability classes (see caption to Fig. 3), each of which was given a different symbol in the magnetostratigraphic plots (Figs. 3, 4 and 5).

The magnetic characteristics appeared to vary with stratigraphic and topographic position. Despite efforts to obtain samples that were as fresh as possible, the influence of alterations due to weathering was not always absent. These alterations cause some ambiguities at several intervals and for clarity the results of the upper Singa and Crotone sections will be treated separately. In general, the characteristic NRM components assessing the normal and reversed polarity zones reveal opposite directions with inclinations systematically lower than the present local geomagnetic direction. These paleomagnetic directions will be the subject of separate studies.

\subsection{Upper Singa section}

Starting immediately above the hiatus in the middle of subsection Singa II, the initial intensity of the NRM is usually well above $2 \mathrm{~mA} / \mathrm{m}$, and often up to $25 \mathrm{~mA} / \mathrm{m}$. There is no or only a small secondary remanence; which is removed at 150 $200^{\circ} \mathrm{C}$ (Fig. 6a). The characteristic remanent magnetization (ChRM) is composite, i.e. thermal demagnetization up to $300-350^{\circ} \mathrm{C}$ first removes a low-temperature (LT) component, up to $480-$ $500^{\circ} \mathrm{C}$ there is almost no decay, and subsequently a high-temperature (HT) component is removed at temperatures up to $600-610^{\circ} \mathrm{C}$ (Fig. 6a). The LT component may reside in an iron-sulphide (pyrrhotite, greigite), whereas the HT component most likely resides in magnetite, which may be slightly cation-deficient considering that blocking temperatures are often higher than $578^{\circ} \mathrm{C}[28,29]$. This NRM composition is identical to that of the early Pliocene Trubi of the lower Singa section [2,28]. A primary origin of the characteristic components has been inferred earlier [2]; a most compelling argument is the positive correlation to the geomagnetic polarity time scale (GPTS) of the polarity pattern based on these characteristic remanences in the lower Singa section.

The paleomagnetic results of the stratigraphic interval immediately above the hiatus reveal a normal polarity. The excellent magnetic properties are continuously present up to sapropel A2. Above this level, the NRM intensity gradually decreases and occasionally some more weathered sites are intercalated. Nevertheless, reliable observations of a two-component ChRM yielding normal polarity continue up to at least level 22.0 $\mathrm{m}$ (Fig. 3). The next few metres enclose sapropel A5 and show low magnetic intensities and intermediate paleomagnetic directions which can be associated with a transition from normal to reversed polarities. The sampling levels between $25.0 \mathrm{~m}$ and the top of the Singa II subsection at $27.0 \mathrm{~m}$ convincingly reveal reversed polarity ChRM directions (Fig. 3).

Subsection Singa III continues the magnetostratigraphic record at $3 \mathrm{~m}$ above sapropel A5 (i.e. at level $27.5 \mathrm{~m}$ in Fig. 3). Approximately at the polarity transition, the NRM changed to a composition that seems typical for the upper Pliocene and lower Pleistocene marine marls of Calabria. The initial intensity is moderate (between 0.2 and $0.5 \mathrm{~mA} / \mathrm{m}$ and occasionally up to $2.0 \mathrm{~mA} / \mathrm{m}$ ) and the NRM consists only of the LT component, which is removed entirely at temperatures near $350^{\circ} \mathrm{C}$ (Fig. 6b). Usually, secondary components are relatively small and removed at $100-200^{\circ} \mathrm{C}$. A subsequent linear decrease towards the origin, up to $350^{\circ} \mathrm{C}$, represents the removal of a well-defined ChRM component which seems to reside exclusively in pyrrhotite or 
greigite. The primary nature of this component is supported by the reversed polarity throughout the Singa III subsection. This consistent picture is only seldomly interrupted by sites with mainly secondary or unreliable magnetizations. Only a single site at level $83.2 \mathrm{~m}$ (Fig. 3) reveals normal polarity, which is represented by the characteristic low blocking temperature $\left(350^{\circ} \mathrm{C}\right)$ component

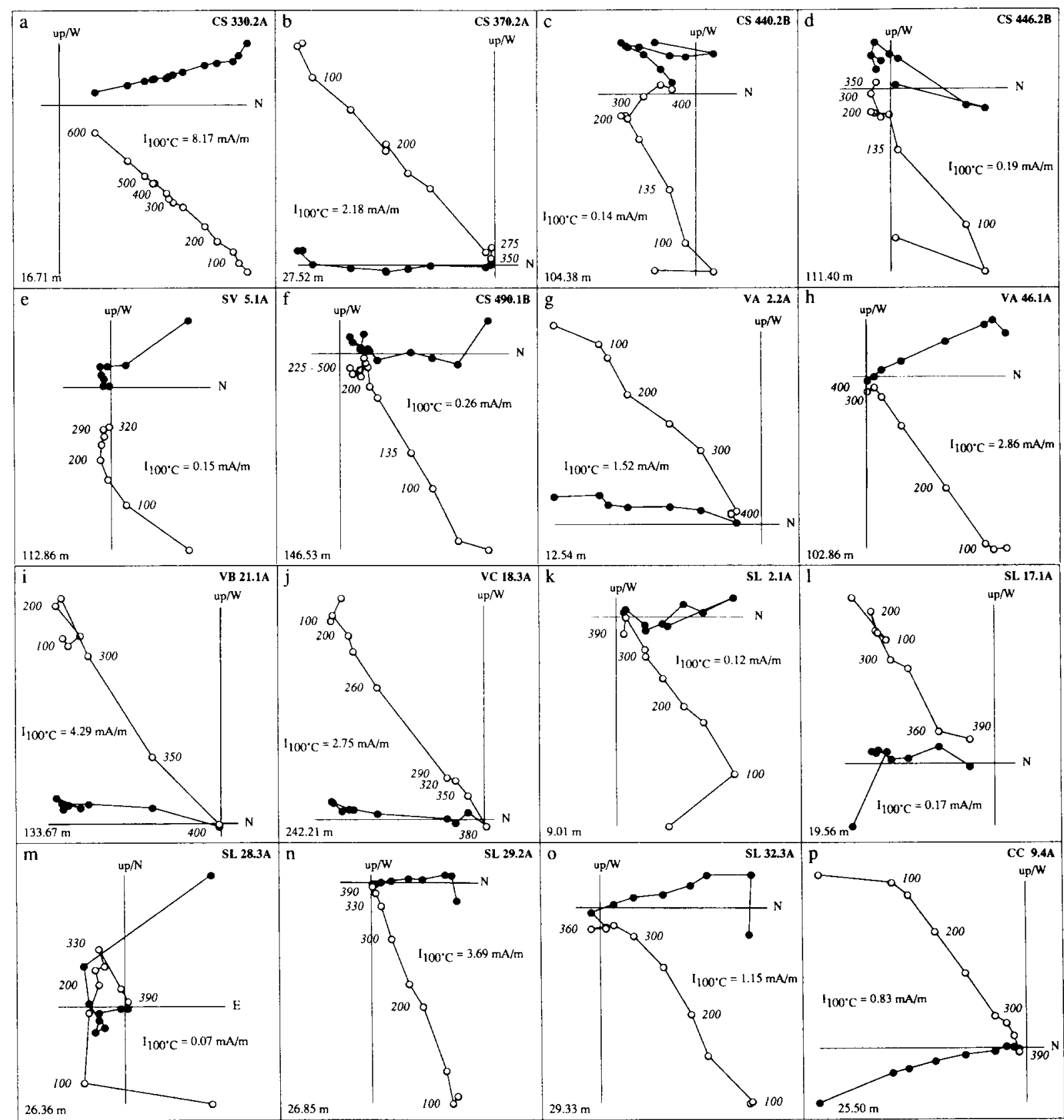

Fig. 6. Some typical examples of progressive thermal demagnetizations of the Pliocene/Pleistocene marine marls. Circles represent positions in orthogonal projection of the resultant NRM vector on the vertical N-S (or E-W) plane; dots represent those on the horizontal plane. Numbers in italics along the projection on the vertical plane are temperatures $\left({ }^{\circ} \mathrm{C}\right)$. The NRM intensity after heating to $100^{\circ} \mathrm{C}$ is given. The number in the bottom left-hand corner of each diagram represents the level of the specimen in its section. In the top right-hand corner the specimen code is found: $C S$ and $S V$ pertain to the upper Singa section, $V A, V B$ and $V C$ to the Vrica sections, $S L$ to the San Leonardo section, and $C C$ to the Crotone section. 
It will be shown that this normal polarity site led to the discovery of the Réunion subzone in the Singa section.

Subsection Singa IV continues the magnetostratigraphic record at $1 \mathrm{~m}$ above sapropel B7 (i.e. at level $91.3 \mathrm{~m}$ ). The magnetic properties and composition of the NRM in the lowermost $11 \mathrm{~m}$ are identical to those described for the preceding Singa III subsection: the polarity stays reliably reversed throughout. The next $11 \mathrm{~m}$ (level 102.1 $\mathrm{m}$ up to level $113.5 \mathrm{~m}$ ) display the influence of increased weathering in the top part of Monte Singa (Fig. 6c, d and e). Weathering is probably promoted by the large number of closely spaced sapropels from the $\mathrm{C}$ group in this interval. Although the presence of a primary LT component with reversed polarity remains perceptible, a relatively large secondary component increasingly dominates the NRM. In the examples shown, the directions of the primary component cannot be reliably determined, although they are seen to be certainly (Fig. 6c and d), or likely (Fig. 6e), of reversed polarity.

From sapropel C1 upwards it was not possible to collect fresh blue marl samples, and indeed, the paleomagnetic results appear to be inconsistent and unreliable. Normal polarities dominate, even at intervals where a reversed polarity can be expected (on the basis of biostratigraphic and sapropel correlations to the sequences in the Crotone area). The NRM has low intensities and often marl specimens reveal only a secondary remanence, a component which is removed at $200^{\circ} \mathrm{C}$ and which has a direction close to the present local field. Further heating results merely in a cluster of vector end points (Fig. 6f), showing that the characteristic LT component has been removed from these weathered marls.

The important stratigraphic interval containing the $\mathrm{C}$ group sapropels straddling the PliocenePleistocene boundary in the Singa area yields insufficient coherent paleomagnetic observations for a reliable polarity zonation owing to the poor state of the section. Therefore, the magnetostratigraphic results for this stratigraphic interval could be obtained from the Crotone area only.

\subsection{Sections of the Crotone area}

The extensive marl sequences in the area south of the town of Crotone contain the three sections used in the present study. The Vrica composite section is the principal one, and the San Leonardo section is parallel to a problematic interval in the central Vrica section. The Crotone section permits extension towards younger Pleistocene marls.

\subsubsection{Vrica section}

The Vrica composite section (Fig. 4) can be divided into three parts on the basis of its magnetic properties. The lower half of the section up to sapropel $\mathrm{C} 4 / \mathrm{c}$ is characterized by relatively high initial NRM intensities (usually 0.5-3.0 $\mathrm{mA} / \mathrm{m}$ ) and an NRM composition which is virtually identical to that of subsection Singa III. Progressive thermal demagnetization generally shows a viscous laboratory component removed at $100^{\circ} \mathrm{C}$, a small secondary component removed at $200^{\circ} \mathrm{C}$, and finally, between 200 and $350^{\circ} \mathrm{C}$, the removal of the characteristic component (Fig. $6 \mathrm{~g}$ ). The primary origin of this characteristic component is indicated by the consistently reversed polarity for the lower $80 \mathrm{~m}$ of the section. A single exception is the normal polarity of one site around the $55 \mathrm{~m}$ level (Fig. 4). The stratigraphic position of this normal polarity site - between sapropels B7 and $\mathrm{CO}-$ is different from the position of the single normal polarity site in the Singa III subsection (just below B5), and consequently relates to another normal polarity subzone. From sapropel C1 upwards to at least sapropel $\mathrm{C} 4 / c$, the characteristic component shows normal polarity (Fig. 6h), indicating a polarity transition at sapropel $\mathrm{C} 1$.

Immediately above sapropel $\mathrm{C} 4 / c$ the initial NRM intensity decreases drastically by one order of magnitude. This intensity decrease marks the beginning of an interval with very low intensities $(0.1-0.2 \mathrm{~mA} / \mathrm{m})$ and consequently leads to demagnetization results which are difficult to interpret. It was often difficult to sample fresh marls, both in the top part of subsection Vrica A, but also in subsection Vrica $B$ in the interval from sapropel $\mathrm{C} 4 / \mathrm{c}$ (level $120.6 \mathrm{~m}$ ) up to half-way between sapropels $\mathrm{C} 6 / e$ and $\mathrm{C} 7$ (at level 147.5 $\mathrm{m}$ ). Indeed, the paleomagnetic results are largely dominated by secondary remanences. Still, the fresh samples between sapropel $\mathrm{C} 4 / c$ and sapropel $\mathrm{C} 5 / d$ indicate a reliable normal polarity. For the interval between sapropel $\mathrm{C} 5 / d$ and sapropel $\mathrm{C} 6 / e$, all fresh samples clearly point to a reversed polarity (Fig. 6i). Thus the normal polarity zone 
extends from sapropel $\mathrm{C} 1$ to sapropel $\mathrm{C} 5 / d$ (Fig. 4).

Low intensities continue above sapropel $\mathrm{C} 6 / e$ and the dominance of secondary remanences obstructs reliable magnetostratigraphic observations. There are indications of a continuation of the reversed polarity above sapropel $\mathrm{C} 6 / e$ up to level $140 \mathrm{~m}$, as well as indications of normal polarities from level $140 \mathrm{~m}$ to $149 \mathrm{~m}$ (Fig. 4). However, this low-intensity interval of the Vrica section is evidently less suitable for reliable magnetostratigraphic study. Therefore, this part of Vrica has been resampled in further detail in the more promising San Leonardo section.

From about half-way between sapropels $\mathrm{C} 6 / e$ and C7 (level $149 \mathrm{~m}$ ) up to the top of subsection Vrica $B$ the initial NRM intensity gradually increases again and the magnetostratigraphic results are more reliable, all revealing reversed polarity (Fig. 4).

Subsection Vrica C continues to show the predominance of reliable reversed NRM types, like those observed in the upper part of subsection Vrica B. There is an evident relationship between the initial intensity and the type of NRM obtained (Fig. 4). The majority of the sites show initial intensities above $0.5 \mathrm{~mA} / \mathrm{m}$ related to the most reliable reversed type: a small laboratory component, remarkably little secondary remanence, and total removal of the reversed primary component below $400^{\circ} \mathrm{C}$. Sites with initial NRM intensities between 0.2 and $0.5 \mathrm{~mA} / \mathrm{m}$ show a small reversed primary component and a dominant secondary overprint removed at high temperatures as well. Reversed polarities are found up to $r$ (Fig. 6j and Fig. 4), although Tauxe et al. [8] found normal polarities from below $\mathrm{C} 13 / q$ up to $\mathrm{C} 14 / \mathrm{s}$. For the present study no reliable samples between $r$ and $\mathrm{C} 14 / s$ could be taken, because in this interval the sediment was too strongly weathered and not a single site with fresh marl could be found.

\subsubsection{San Leonardo section}

The San Leonardo section was sampled as a less weathered substitute for the low-intensity interval in the middle of the Vrica section. Sampling stretches from $5 \mathrm{~m}$ below sapropel $\mathrm{C} 5 / d$ and up to just below sapropel $\mathrm{C} 8 / f$.
In spite of the better prospects, the initial NRM intensities were low (usually between 0.1 and $0.5 \mathrm{~mA} / \mathrm{m}$ ), although occasionally some higher intensities were measured. Thermal demagnetization diagrams (Fig. 6k) show the presence of a normal polarity characteristic remanence up to sapropel $\mathrm{C} 5 / d$. The entire interval between sapropels $\mathrm{C} 5 / d$ and $\mathrm{C} 6 / e$ reveals a characteristic component with a reversed polarity, in spite of the sometimes very low intensities (Fig. 61). The reversed polarity zone between sapropel $\mathrm{C} 5 / d$ and $\mathrm{C} 6 / e$ in the Vrica section is thus reliably confirmed. The $\mathrm{N}-\mathrm{R}$ polarity transition is situated near the bottom of sapropel $\mathrm{C} 5 / d$ on the basis of, both in the San Leonardo section and in the Vrica section, a site just below sapropel $C 5 / d$ revealing a single specimen indicating the presence of a reversed polarity component.

The subsequent stratigraphic interval of $4 \mathrm{~m}$ above sapropel $\mathrm{C} 6 / e$ yields extremely low NRM intensities (below 0.08-0.16 $\mathrm{mA} / \mathrm{m}$ ). Despite these very low intensities, thermal demagnetization reveals, in addition to a large secondary overprint, the presence of a very small, but nevertheless clearly defined, reversed component (Fig. $6 \mathrm{~m})$. The reversed polarity zone, which starts near the bottom of sapropel $\mathrm{C} 5 / d$, thus continues upward to about $4 \mathrm{~m}$ above sapropel $\mathrm{C} 6 / e$ (i.e., level $26.5 \mathrm{~m}$ in Fig. 5).

The next $4 \mathrm{~m}$ (level $26.5 \mathrm{~m}$ to $30.5 \mathrm{~m}$ (Fig. 5)) shows higher NRM intensities $(0.3-3.7 \mathrm{~mA} / \mathrm{m})$ and normal directions throughout the entire progressive thermal demagnetization up to total removal of the NRM below $400^{\circ} \mathrm{C}$ (Fig. 6n and o, Fig. 5), indicating that this stratigraphic interval might represent a true normal polarity zone. From level $30.5 \mathrm{~m}$ upward (Fig. 5) NRM intensities vary greatly, but only reversed components are found for the entire upper part of this section.

Thus, the magnetostratigraphic results of the San Leonardo section essentially confirm the results of the central part of the Vrica section. The lower normal polarity zone which starts at sapropel $\mathrm{C} 1$ in the Vrica section continues up to just below sapropel $\mathrm{C} 5 / d$. The interval between sapropel $\mathrm{C} 5 / d$ and $\mathrm{C} 6 / e$ represents a reversed polarity zone, which continues up to $4 \mathrm{~m}$ above sapropel $\mathrm{C} 6 / e$, while the interval between level $26.5 \mathrm{~m}$ and $30.5 \mathrm{~m}$ represents a normal polarity subzone. The upper part of the San Leonardo 
section above level $30.5 \mathrm{~m}$ reveals reversed polarities only.

\subsubsection{Crotone section}

The interval above sapropel $r$ has been sampled in a section located in the southern outskirts of the town of Crotone (Fig. 1). This Crotone section stretches from some $20 \mathrm{~m}$ below sapropel $\mathrm{C} 13 / q$ up to sapropel $u$, and thus has an ample overlap with the top part of the Vrica section which Tauxe et al. [8] designated as their normal polarity zone N3. The magnetostratigraphic results from the Crotone section, however, based on fresh and blue-coloured marls, reveal a reversed polarity throughout (Fig. 6p). All sites up to level $61.0 \mathrm{~m}$ (Fig. 5) show relatively high NRM intensities and reversed magnetizations, with a small secondary remanence.

\section{Magnetostratigraphy of the Plio-Pleistocene}

The upper Singa section starts with an interval with stable normal polarity directions. A normal to reversed polarity transition is found at the level of sapropel A5. From this level up to sapropel $\mathrm{C} 1$ only reversed polarities are found, with the exception of a single site just below sapropel B5 which reveals a stable normal polarity. From $\mathrm{C} 1$ upward no reliable polarity zonation can be established. Predominantly normal polarities occur, most of which are clearly of secondary origin due to the intense weathering.

In the Crotone area, reversed polarities occur from sapropel $\mathrm{B} 6$ to $\mathrm{C} 1$ as well, with a single site (level $55 \mathrm{~m}$ ) showing normal polarity. A normal polarity interval is found between $\mathrm{C} 1$ and $\mathrm{C} 5 / d$ and is followed by a reversed interval. There is evidence of a short $(4 \mathrm{~m})$ normal polarity zone above sapropel $\mathrm{C} 6 / e$. From above the short normal polarity zone up to sapropel $r$ in the composite Vrica section (Fig. 4) and up to sapropel $u$ in the Crotone section (Fig. 5) only reversed polarities occur.

The small number of complete polarity zones renders a statistical correlation to the geomagnetic polarity time scale by means of the pattern of the successive polarity zones unfeasible. Nevertheless, the Plio-Pleistocene age and the prevailing reversed polarities places the stratigraphic interval undoubtedly in the Matuyama Chron (Fig.
7). The long reversed polarity zones both below and above the relatively short interval with normal polarities identifies this central normal zone as representing the Olduvai subchron. The lowermost normal polarity zone in the upper Singa section has been correlated previously to the youngest part of the Gauss chron [7].

Seeing as the lower boundary of the Olduvai subzone is located at the level of sapropel $\mathrm{C} 1$, the stratigraphic interval in the upper Singa section between sapropels A5 (Gauss/Matuyama) and $\mathrm{C} 1$ corresponds to the lowest Matuyama reversed subchron. The normal polarity site just below B5 may therefore represent the Réunion subchron. The single normal polarity site below the lower Olduvai boundary in the Vrica section certainly does not represent the same subchron because it is located distinctly higher (between $\mathrm{B} 7$ and $\mathrm{C} 0$ ) in the succession. A detailed investigation of the intervals in question is currently being carried out.

There are some essential differences between the present record and that published by Tauxe et al. [8] for the same stratigraphic interval (Fig. 7). The lower Olduvai polarity transition is more precisely pinpointed, mainly because of the much higher sampling density, and it is located at the level of sapropel $\mathrm{C} 1$, some $9 \mathrm{~m}$ below sapropel $\mathrm{C} 2 / a$, whereas Tauxe et al. [8] located this boundary $25 \mathrm{~m}$ below sapropel $a$. More interestingly, Tauxe et al. have interpreted their two sites between sapropels $b$ and $c$ to be of reversed polarity (their zone R3), whereas the present study reveals only normal polarity results at twelve sites divided over this stratigraphic interval. The normal polarity of their site 18 (i.e., their zone N2) between sapropels $c$ and $d$ is confirmed by our results, and in both studies a polarity transition from normal to reversed is placed at sapropel $d$. The interval between sapropel $d$ and a level half-way between sapropels $e$ and $f$ is interpreted by Tauxe et al. to belong to their reversed zone R4, although they do not present any data. The present study, however, reveals an additional interval of normal polarity, $4 \mathrm{~m}$ above sapropel $e$. Finally, the normal polarity zone N3 of Tauxe et al. from below sapropel $q$ up to $s$ is not confirmed. The present study reveals only reversed polarities, both in the Vrica section (up to sapropel $r$ ) and in the Crotone section (from below 


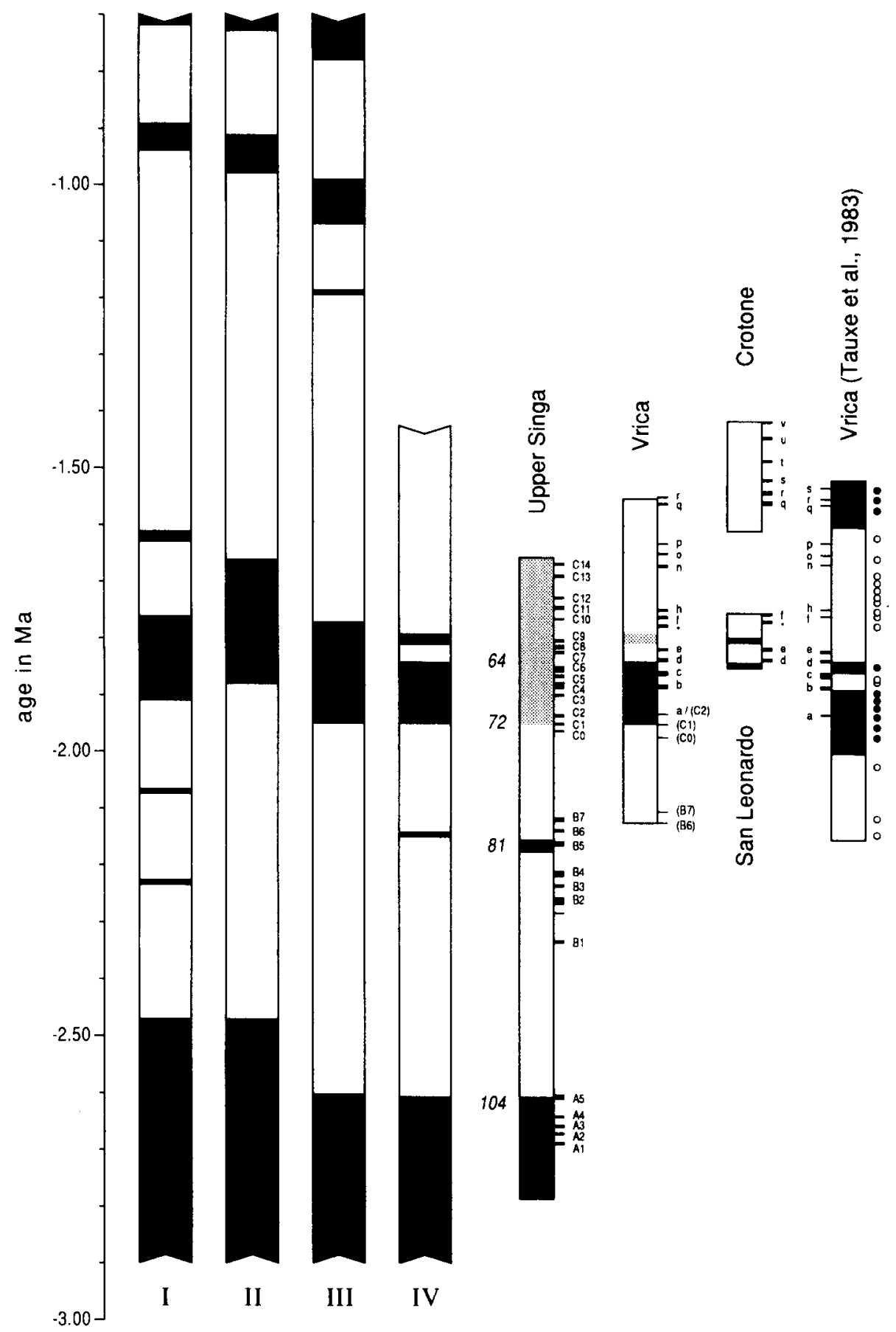

Fig. 7. Correlation of the magnetic polarity zones observed in the Calabrian Late Pliocene/Early Pleistocene sections to the geomagnetic polarity time scale. The four polarity time scales to the left: $\mathrm{I}=$ McDougall [30] and II = Berggren et al. [31] are dated radiometrically, and III = Shackleton et al. [32] and IV = Hilgen [1] are dated by means of astronomical calibrations. For the construction of scale IV the paleomagnetic data of the present study were used. The polarity zonation observed in the upper Singa, Vrica, San Leonardo and Crotone sections is seen to the right. The polarity zonation of the Vrica section as reported by Tauxe et al. [8] is shown on the far right. Numbers in italics to the left of the upper Singa column represent isotopic stages observed in the upper Singa section by Lourens et al. [24]. Positions and numbering of the sapropels given for each of the sections. The correlation between the sections is based on the sapropels (cf. Fig. 2). Circles along the right-hand side of the Vrica section of Tauxe et al. (1983) represent the number and position of the reversed polarity specimens given in [8]; the dots represent the number and position of the normal polarity specimens. 
sapropel $q$ up to $u$ ). The normal polarities clearly represent secondary magnetizations as a result of increased weathering in the top of the section.

An incorrect identification of the sapropels as a possible explanation for the discrepancies between our results and those of Tauxe et al. [8] can be excluded because of the very distinct and characteristic pattern in thickness and clustering of the sapropels as well as of other lithological marker beds in the Vrica sections.

\section{Discussion}

The Gauss/Matuyama polarity transition in the upper Singa section precedes the multiple Discoaster ( $D$. pentaradiatus, D. surculus) extinction event and, in terms of planktonic foraminifera, the LO of $G$. punticulata and $N$. atlantica, and it succeeds the LO of D. tamalis, similar to the results obtained during ODP Leg 94. Moreover, isotopic stage 104 of Raymo et al. [25] is almost coeval with this polarity transition $[7,24]$.

The normal polarity site just below sapropel B5 and probably corresponding to the Réunion subchron occurs in isotopic stage 81 [24]. At ODP Site 609 , normal polarities were found in the same isotopic stage, and have also been interpreted in terms of the Réunion subchron [25]. An additional biostratigraphic argument supporting the proposal that we are dealing with one and the same subchron is the FO of $G$. inflata, which is recorded slightly higher in the succession, i.e., in isotopic stage 79 , both in the upper Singa section and at ODP Site 609 [25].

The lower boundary of the Olduvai subzone at $\mathrm{C} 1$ is located in isotopic stage 72 , both in the upper Singa section [24] and at ODP Site 609 [25], and coincides closely with the LO of $D$. brouweri (Fig. 2). At Site 609, the lower Olduvai polarity transition was initially placed at a lower level - in isotopic stage 73 - but a subsequent and more detailed study has revealed that this initial position was based on a single site of normal polarity well below the actual lower Olduvai boundary [25]. In the upper Singa and Vrica sections, at the level of isotopic stage 73 no normal polarities have thus far been observed. At Vrica a single normal polarity site is found to coincide with the FO of $G$. truncatulinoides. In the Singa section, however, this influx appears to correspond to isotopic stage 75 .

The position of the upper boundary of the Olduvai subzone at Vrica is very important because of the formal definition of the PliocenePleistocene boundary on top of sapropel $e$ in this section. The present study reveals two options for the position of the upper boundary of the Olduvai subzone. This boundary can be placed either at the level of sapropel $\mathrm{C} 5 / d$, implying that an extra normal subchron - the Vrica subchron is present above sapropel C6/e (option I), or it can be placed at the top of the extra normal polarity interval just mentioned (option II). The latter option implies that a reversed polarity interval is present in the top part of the Olduvai subchron. The further implications of the two options are as follows:

At ODP Sites 607 and 609, and at Site 552, the top of the Olduvai subzone is recorded invariably in isotopic stage 64. An argument in favour of option II is that correlation of isotopic stages between the ODP sites and the Calabrian sections shows that stage 64 is situated at the top of the extra normal polarity interval. This correlation is supported by the first common occurrence (FCO) of left-coiling neogloboquadrinids slightly below the upper Olduvai polarity transition in the northern Atlantic, as well as slightly below the top of the extra normal polarity interval in the Vrica and San Leonardo sections (Figs. 4 and 5).

The inferred duration of the Olduvai subzone provides another argument in favour of option II. The duration of the Olduvai subzone in the Vrica section can be determined accurately for both options by using the astronomical ages of the sedimentary (sapropel) cycles [1], and provides estimates of $115 \mathrm{ka}$ for option I and $160 \mathrm{ka}$ for option II. The duration of $115 \mathrm{ka}$ is considerably less than reported for the Olduvai subchron in the literature. Linear interpolation between the Gauss/Matuyama and the Matuyama/Brunhes boundary in deep-sea cores yields an average duration of $150 \mathrm{ka}$ (1.91-1.76 Ma; [30,33]), whereas analysis of near-bottom marine magnetic anomalies yields a duration of $220 \mathrm{ka}(1.88-1.66$ $\mathrm{Ma} ;[31,34,35])$. The second value is closely approached by the duration of $200 \mathrm{ka}$ (1.87-1.67 $\mathrm{Ma})$ in the polarity time scale of Mankinen and 
Dalrymple [36], who apparently placed the boundaries at the oldest and youngest $\mathrm{K} / \mathrm{Ar}$ ages of absolutely dated normal polarity observations. A duration of $160 \mathrm{ka}$ for the Olduvai subchron agrees well with other astronomically based estimates of $170 \mathrm{ka}(1.82-1.65 \mathrm{Ma}$; [25]) and $180 \mathrm{ka}$ (1.95-1.77 Ma; [32]).

Summarizing, it can be concluded that the top of the extra normal polarity interval above sapropel $e$ most probably represents the upper Olduvai polarity transition as generally found elsewhere.

This conclusion implies that a reversed interval is present in the upper part of the Olduvai subchron. Such a reversed interval has not been observed in cores from ODP Leg 94, nor in many other deep-sea cores, but it was found earlier in core V20-109 by Ninkovitch et al. [37,38]. Furthermore, several Indian Ocean deep-sea cores have revealed the presence of a single site with reversed polarity just below the upper boundary of the Olduvai subzone [39]. Nevertheless, Mankinen and Dalrymple [36] conclude that the lack of sufficient confirmation in other cores prevents the unambiguous recognition of reversed polarities below the upper boundary of the Olduvai subzone (or a short normal polarity event following the Olduvai subchron). The lack of sufficient confirmation, however, might rather be due to a lack of sufficiently detailed sampling. More recently, Heller et al. [40] found a short reversed polarity interval in the top part of the Olduvai subzone in loess deposits of the Chinese Loess Plateau.

The presence of a reversed interval in the upper part of the Olduvai subzone also raises a problem in terminology. The classical Olduvai interval has been denoted as a subchron and the reversed interval would place a subchron within a subchron. The alternative would be to redefine the extent of the Olduvai subchron and to distinguish a sequence of a relatively long normal subchron (the Olduvai according to option I), a short reversed subchron, and an even shorter normal subchron (the "Vrica subchron"), with respective durations of 115, 30 and $15 \mathrm{ka}$. For comparison, on the basis of a sedimentation rate of $0.8 \mathrm{~cm} / \mathrm{ka}$ Ninkovitch et al. [37] deduced durations of 106, 11 and $24 \mathrm{ka}$ for their subchrons in core V20-109, amounting to a total duration of $141 \mathrm{ka}$.
The following aspect to be discussed is a possible identity for the Vrica subchron and the Gilsa subchron. During Leg 94, an additional normal polarity chron of very short duration $(5.5 \mathrm{ka})$ was found above the Olduvai, corresponding to isotopic stage 54, which was interpreted to represent the Gilsa subchron [41]. The Gilsa subchron was originally found in Eastern Iceland $[42,43]$, and was based on a possibly reversed lava flow between the third and fourth flow of a sequence of normally magnetized lava flows representing the Olduvai subchron. A detailed study of these flows by Watkins et al. [44] suggested that the reversed tendency and the much lower intensities of the single intervening flow was due to "magnetic instability". Watkins et al. [44] obtained average $\mathrm{K} / \mathrm{Ar}$ ages of $1.68 \pm 0.01$ and $1.59 \pm 0.01 \mathrm{Ma}$ for the third and fourth flow respectively. The authors rejected the presence of the Gilsa event and the obtained ages have been merged to a single $1.62 \pm 0.08 \mathrm{Ma}$ for the younger part of the Olduvai subchron. However, were we to accept the presence of a short reversed interval between the third and fourth flow, a maximum duration of 90 ka (1.68-1.59 Ma) would be inferred; the actual duration may be appreciably shorter. A duration of approximately $30 \mathrm{ka}$ can be established for the reversed interval in San Leonardo, whereas the inferred duration of the reversed interval between the upper Olduvai boundary (isotopic stage 64) and the "Gilsa" (stage 54) in Leg 94 is approximately $140 \mathrm{ka}$, longer than the maximum possible duration inferred from the Icelandic lavas. Hence, it is very unlikely that the Vrica subchron at stage 64 is identical with the "stage 54 subchron" in Leg 94. Moreover, considering the ambiguities concerning the original Gilsa event in the Icelandic lavas, we shall refrain from interpreting the Vrica subchron as the Gilsa subchron.

\section{Conclusions}

The results from the Monte Singa area show that a reliable magnetostratigraphy can be established from below the Gauss/Matuyama boundary (correlated to isotopic stage 104) up to and including the lower Olduvai boundary (isotopic stage 72). Normal polarities just below sapropel $\mathrm{B} 5$, at a level corresponding to isotopic stage 81 , 
most likely represent the Réunion subchron. From the lower Olduvai boundary upward, a reliable magnetostratigraphy could not be established, due to increased weathering of the marls resulting in mainly secondary magnetizations.

The sequences from the Crotone area (i.e., the Vrica, San Leonardo and Crotone sections) belong to the reversed Matuyama Chron, and are younger than the Réunion subchron. They include the Olduvai subchron, but the positions found for both the lower and upper boundary of the Olduvai subzone differ markedly from those reported by Tauxe et al. [8]. Besides, the normal polarities reported for the top part of the Vrica section [8] are not confirmed by the results from the fresh outcrops of the parallel Crotone section. Given the very weathered state of the top part of the Vrica section these normal polarities are almost certainly due to secondary magnetizations related to the weathering and do not represent an extra normal subchron.

Two options exist for the position of the upper boundary of the Olduvai subzone. In option I, the Olduvai subzone is positioned between sapropels $\mathrm{C} 1$ and $\mathrm{C} 5 / d$ and has a duration of $115 \mathrm{ka}$, followed by a short ( $30 \mathrm{ka}$ ) reversed subchron and the short (15 ka) normal Vrica subchron. In option II, the Olduvai subzone is positioned between sapropel $\mathrm{C} 1$ and a level half-way between $\mathrm{C} 6 / e$ and $\mathrm{C} 7$, and has a duration of $160 \mathrm{ka}$, implying a short reversed interval in its upper part. The latter option is in good agreement with the position and age of the upper Olduvai boundary as reported in the literature.

\section{TABLE 1}

Stratigraphic positions (in metres) of magnetostratigraphic and biostratigraphic datum planes in the studied sections. Positions of calcareous nannofossil events derived from the work of Driever ([23] and unpublished data). Also shown are the ages (in Ma) of these datum planes. Ages 1 are based on linear interpolation and extrapolation of conventional radiometric ages for geomagnetic polarity reversals [31]; ages 2 are based on linear interpolation between astronomically dated sapropels [1]

\begin{tabular}{|c|c|c|c|c|c|c|c|c|}
\hline \multirow{2}{*}{\multicolumn{2}{|c|}{ Reversal boundary }} & \multicolumn{4}{|c|}{ Stratigraphic position } & \multirow{2}{*}{$\begin{array}{l}\text { Isotopic } \\
\text { Stage }\end{array}$} & \multicolumn{2}{|c|}{ Age } \\
\hline & & Singa & Vrica & S. Leonardo & Crotone & & 1 & 2 \\
\hline \multirow{2}{*}{\multicolumn{2}{|c|}{$\begin{array}{l}\text { "Upper Olduvai" (option II) } \\
\text { "Upper Olduvai" (option I) }\end{array}$}} & - & $144.5-145.5$ & $29.3-30.8$ & & 64 & 1.66 & 1.79 \\
\hline & & & $127.1-129.8$ & 12.5 & & & & 1.84 \\
\hline \multicolumn{2}{|c|}{ Lower Olduvai } & 112.6 & $80.1-83.1$ & & & 72 & 1.88 & 1.95 \\
\hline \multirow{2}{*}{\multicolumn{2}{|c|}{ n-polarity }} & & 54.2 & & & 75 & - & 2.01 \\
\hline & & 85.4 & & & & 81 & - & 2.14 \\
\hline \multirow{2}{*}{\multicolumn{2}{|c|}{$\begin{array}{l}\text { Reunion bottom } \\
\text { Gauss/Matuyama }\end{array}$}} & $82.1-83.2$ & & & & 81 & - & 2.15 \\
\hline & & 24 & & & & 104 & 2.47 & 2.60 \\
\hline \multicolumn{9}{|c|}{ Blohorizon (foraminiferal) } \\
\hline FCO & sinistral neoglob. & $126.6-127.1$ & $139.4-141.2$ & $25.4-25.9$ & & 64 & 1.68 & 1.80 \\
\hline & S. dehiscens & $105.4-105.9$ & $54.8-58.8$ & & & 74 & 1.93 & 1.98 \\
\hline re-ap. & G. inflata & $104.9-105.4$ & $61.8 \cdot 63.4$ & & & $73 / 74$ & 1.93 & 1.99 \\
\hline FO & G. truncatulinoides & $102.9-103.4$ & $50.8-52.7$ & & & 75 & 1.95 & 2.00 \\
\hline FO & G. inflata & $91.4-91.9$ & $19.2-21.7$ & & & $77 / 78$ & 2.02 & 2.09 \\
\hline FO & S. dehiscens & $76.8 \cdot 77.0$ & & & & 83 & 2.12 & 2.19 \\
\hline & G. puncticulata & $47.3-47.8$ & & & & $95 / 96$ & 2.31 & 2.41 \\
\hline LO & N. atlantica & $47.3-47.8$ & & & & $95 / 96$ & 2.31 & 2.41 \\
\hline FO & N. atlantica & $12.1-12.7$ & & & & 110 & 2.57 & 2.72 \\
\hline \multicolumn{9}{|c|}{ Biohorizon (nannolossils) } \\
\hline base & small gephyrocapsids & & & & $76.3-78.1$ & $?$ & 1.18 & $?$ \\
\hline LAD & H. selli & & & & $74.7-76.3$ & $?$ & 1.19 & $?$ \\
\hline LAD & C. macintyrei & $136.4-136.9$ & & & & $?$ & 1.54 & $?$ \\
\hline FAD & G. caribbeanica & $130.3-132.2$ & & & & $?$ & 1.61 & 1.74 \\
\hline FAD & D. brouweri & $111.9-112.4$ & & & & 72 & 1.88 & 1.95 \\
\hline LAD & D. pentaradiatus & $34.3-34.8$ & & & & 100 & 2.40 & 2.51 \\
\hline LAD & D. surculus & $29.3-31.3$ & & & & 101 & 2.43 & 2.55 \\
\hline LAD & D. tamalis & $7.5-9.0$ & & & & $112 ?$ & 2.61 & 2.76 \\
\hline
\end{tabular}


Linear interpolation and extrapolation on the basis of the observed polarity transitions and use of the radiometric ages for them of the geomagnetic polarity time scale of Berggren et al. [33] yields the ages for the late Pliocene-early Pleistocene biostratigraphic datum levels shown in Table 1 . In addition, an age of $1.69 \mathrm{Ma}$ is found for the Pliocene-Pleistocene boundary if we use option II for the upper boundary of the Olduvai subzone.

The positions of the polarity transitions determined in the present study form the basis of the new geomagnetic polarity time scale of Hilgen [1]. This time scale has been established by the astronomical calibration of sapropel patterns, using the interference pattern of precession and eccentricity of the Earth's orbit. This astronomical calibration leads to ages for the polarity transitions systematically older than the conventional ages based on radiometric dating. According to this new time scale the Pliocene-Pleistocene boundary has an age of $1.81 \mathrm{Ma}$. The astronomical ages of the biostratigraphic datum levels are also given in Table 1.

\section{Acknowledgements}

Thanks go to P.J. Verplak for his assistance in the field, again to P.J. Verplak and also to H.J. Meijer for measuring the enormous number of samples, to $T$. van Hinte for the skillful illustrations and to G.J. van 't Veld and G. Ittman for the preparation of the micropaleontological samples. We thank M.B. Cita, C. Kissel and W. Lowrie for reviewing the manuscript. This investigation was partly supported by the Netherlands Foundation for Earth Sciences (AWON) with financial aid from the Netherlands Organization for Scientific Research (NWO). A travel grant from Shell Internationale Petroleum Maatschappij B.V. (The Hague) is gratefully acknowledged.

\section{References}

1 F.J. Hilgen, Astronomical calibration of Gauss to Matuyama sapropels in the Mediterranean and implication for the Geomagnetic Polarity Time Scale, Earth Planet. Sci. Lett. 104, 226-244, 1991.
2 J.D.A. Zijderveld, W.J. Zachariasse, P.J.J.M. Verhallen and F.J. Hilgen, The age of the Miocene-Pliocene boundary, Newslett. Stratigr. 16, 169-181, 1986.

3 F.J. Hilgen and C.G, Langereis, The age of the MiocenePliocene boundary in the Capo Rossello area (Sicily), Earth Planet. Sci. Lett. 91, 214-222, 1988.

4 J.E.T. Channell, D. Rio and R.C. Thunell, Miocene/ Pliocene boundary magnetostratigraphy at Capo Spartivento, Calabria, Italy, Geology 16, 1096-1099, 1988.

5 C.G. Langereis and F.J. Hilgen, The Rossello composite: A Mediterranean and global standard reference section for the Early to early Late Pliocene, Earth Planet. Sci. Lett. 104, 211-225, 1991.

6 W.J. Zachariasse, J.D.A. Zijderveld, C.G. Langereis, F.J. Hilgen and P.J.J.M. Verhallen, Early Late Pliocene biochronology and surface water temperature variations in the Mediterranean, Mar. Micropaleontol. 14, 339-355, 1989.

7 W.J. Zachariasse, L. Gudjonsson, F.J. Hilgen, C.G. Langereis, L.J. Lourens, P.J.J.M. Verhallen and J.D.A. Zijderveld, Late Gauss to early Matuyama invasions of Neogloboquadrina atlantica in the Mediterranean and associated record of climatic change, Paleoceanography 5, 239-252, 1990.

8 L. Tauxe, N.D. Opdyke, G. Pasini and C. Elmi, Age of the Plio-Pleistocene boundary in the Vrica section, southern Italy, Nature 304, 125-129, 1983.

9 F.J. Hilgen, Closing the gap in the Plio-Pleistocene boundary stratotype sequence of Crotone (southern Italy), Newslett. Stratigr. 22, 43-51, 1990.

10 F.J. Hilgen, Sedimentary rhythms and high-resolution chronostratigraphic correlations in the Mediterranean Pliocene, Newslett. Stratigr. 17, 109-127, 1987.

11 F.J. Hilgen and C.G. Langereis, Periodicities of $\mathrm{CaCO}_{3}$ cycles in the Mediterranean Pliocene: Discrepancies with the quasi-periods of the Earth's orbital cycles?, Terra Nova 1, 409-415, 1989.

12 F.J. Hilgen, Extension of the astronomically calibrated (polarity) time scale to the Miocene/Pliocene boundary, Earth. Planet. Sci. Lett. 107, 349-368, 1991.

13 R.B. Kidd, M.B. Cita and W.B.F. Ryan, Stratigraphy of eastern Mediterranean sapropel sequences recovered during DSDP Leg 42A and their paleoenvironmental significance, Init. Rep. DSDP 42A, 421-443, 1978.

14 E. Olausson, Description of sediment from the Mediterranean and Red Sea, Rep. Swed. Deep-Sea Exped., 19471948 8, 337-391, 1961.

15 P.J.J.M. Verhallen, Early development of Bulimina marginata in relation to paleo-environmental changes in the Mediterranean, K. N. Akad. Wet., Verh. B 90, 161-180, 1987.

16 E. Aguirre and G. Pasini, The Pliocene-Pleistocene boundary, Episodes 8, 116-120, 1985.

17 G. Pasini, R. Selli, R. Tampieri, M.L. Colalongo, S. d'Onofrio, A.M. Borsetti and F. Cati, The Vrica section, in: The Neogene-Quaternary boundary, II Symp. Bologna-Crotone, Excursion Guide-book, R. Selli, ed., pp. $62-72,1975$.

18 R. Selli, C.A. Accorsi, M. Bandini Mazzanti, D. Bertolani Marchetti, G. Bigazzi, F.P. Bonadonna, A.M. Borsetti, F. 
Cati, M.-L. Colalongo, S. d'Onofrio, W. Landini, E. Menesini, R. Mezzeti, G. Pasini, G. Savelli and R. Tampieri, The Vrica section (Calabria). A potential NeogeneQuaternary boundary stratotype, G. Geol. 41, 181-204, 1977.

19 J.D. Obradovitch, C.W. Naeser, G.A. Izett, G. Pasini and G. Bigazzi, Age constraints on the proposed Plio-Pleistocene boundary stratotype at Vrica, Italy, Nature 298, 55$59,1982$.

20 J. Backman, N.J. Shackleton and L. Tauxe, Quantitative nannofossil correlation to open ocean deep-sea sections from Plio-Pleistocene boundary at Vrica, Italy, Nature $304,156-158,1983$.

$21 \mathrm{P}$. Spaak, Accuracy in correlation and ecological aspects of the planktonic foraminiferal zonation of the Mediterranean Pliocene, Utrecht Micropaleontol. Bull. 28, 1-160, 1983.

22 M.B. Cita, The Miocene/Pliocene boundary. History and definition, in: Late Neogene Epoch Boundaries, T. Saito and L.H. Burckle, Micropaleontol. Press Spec. Publ. 1, 1-30, 1975.

23 B.W.M. Driever, Calcareous nannofossil biostratigraphy and paleoenvironmental interpretation of the Mediterranean Pliocene, Utrecht Micropaleontol. Bull. 36, 245, 1988.

24 L.J. Lourens, F.J. Hilgen and W.J. Zachariasse, Late Pliocene-early Pleistocene astronomically forced surface water temperatures and productivity variations in the Mediterranean, Mar. Micropaleontol., in press, 1991.

25 M.E. Raymo, W.F. Ruddiman, J. Backman, B.M. Clement and D.G. Martinson, Late Pliocene variation in northern hemisphere ice sheets and North Atlantic deep water circulation, Paleoceanography 4, 413-446, 1989.

26 D. Rio, R. Sprovieri and J.E.T. Channell, Pliocene-early Pleistocene chronostratigraphy and the Tyrrhenian deepsea record from Site 653, Proc. ODP, Sci. Results 107, $705-715,1990$.

27 D. Rio, R. Sprovieri and I. Raffi, Calcareous plankton biostratigraphy and biochronology of the Pliocene--lower Pleistocene succession of the Capo Rossello area, Sicily, Mar. Micropaleontol. 9, 135-180, 1984.

28 J.H. Linssen, Preliminary results of a study of four successive sedimentary geomagnetic reversal records from the Mediterranean (upper Thvera, lower and upper Sidufjall, lower Nunivak). Phys. Earth Planet. Inter. 52, 207-231, 1988.

29 F. Heider and D.J. Dunlop, Two types of chemical remanent magnetization during the oxidation of magnetite, Phys. Earth Planet. Inter. 46, 24-45, 1987.

30 I. McDougall, The present status of the geomagnetic po- larity time scale, in: The Earth, its Origin, Structure anc Evolution, M.W. McElhinny, ed., pp. 543-565, Academic Press, New York, 1979.

31 W.A. Berggren, D.V. Kent, J.J. Flynn and J.A. Van Couvering, Cenozoic geochronology, Geol. Soc. Am. Bull. 96 , 1407-1418, 1985.

32 N.J. Shackleton, A. Berger and W.R. Peltier, An alterna tive astronomical calibration of the lower Pleistocene timescale based on ODP Site 677, Trans. R. Soc. Edinb. Earth Sci. 81, 251-261, 1990.

33 N.D. Opdyke, Paleomagnetism of deep-sea cores, Rev. Geophys. Space Phys. 10, 213-249, 1972.

34 K.D. Klitgord, S.P. Huestis, J.D. Mudie and R.L. Parker, An analysis of near-bottom magnetic anomalies: Sea-floor spreading and the magnetized layer, Geophys. J. R. Astron. Soc. 43, 387-424, 1975.

35 J.L. LaBrecque, D.V. Kent and S.C. Cande, Revised magnetic polarity time scale for Late Cretaceous and Cenozoic time, Geology 5, 330-335, 1977.

36 E.A. Mankinen and G.B. Dalrymple, Revised geomagnetic polarity time scale for the interval $0-5$ m.y. B.P., J. Geophys. Res. 84, 615-626, 1979.

37 D. Ninkovitch, N.D. Opdyke, B.C. Heezen and J.H. Foster, Paleomagnetic stratigraphy, rates of deposition and tephrachronology in North Pacific deep sea sediments, Earth Planet. Sci. Lett. 1, 476-492, 1966.

38 N.D. Watkins, Short period geomagnetic polarity events in deep sea sedimentary cores, Earth Planet. Sci. Lett. 4, $341-349,1968$.

39 N.D. Opdyke and B.P. Glass, The paleomagnetism of sediment cores from the Indian Ocean, Deep-Sea Res. 16, 249-261, 1969.

40 F. Heller, X.M. Liu, T.S. Liu and T.C. Xu, Magnetic susceptibility of loess in China, Earth Planet. Sci. Lett. 103, 301-310, 1991.

41 B.M. Clement and D.V. Kent, Short polarity intervals within the Matuyama: transitional field records from hydraulic piston cored sediments from the North Atlantic, Earth Planet. Sci. Lett. 81, 253-264, 1986/1987.

$42 \mathrm{H}$. Wensink, Secular variation of earth magnetism in PlioPleistocene basalts of eastern Iceland, Geol. Mijnbouw 43 , 403-413, 1964.

43 H. Wensink, Paleomagnetic stratigraphy of younger basalts and interval Plio-Pleistocene tillites in Iceland, Geol. Rundsch. 54, 364-384, 1964.

44 N.D. Watkins, L. Kristjansson and I. McDougall, A detailed paleomagnetic survey of the type location for the Gilsa geomagnetic polarity event, Earth Planet. Sci. Lett. $27,436-444,1975$. 